Original Article

\title{
THE REASONS FOR THE DIFFERENT NEST SHAPES OF MEGAPIS BEES
}

\author{
Jerzy Woyke1 * \\ Jerzy Wilde W $^{2}$ \\ Maria Wilde 3 \\ 'Division of Apiculture, University of Life Sciences (SGGW), 166 Nowoursynowska, \\ 02-787 Warsaw, Poland, \\ ${ }^{2}$ Apiculture Division, University of Warmia and Mazury in Olsztyn, 48 Słoneczna, \\ 10-957 Olsztyn, Poland, \\ 3Honey bee Breeding Centre, Gryżliny, 11-034 Stawiguda, Poland \\ * corresponding author: jerzy_woyke@sggw.pl \\ Received 25 November 2015; accepted 27 February 2016
}

\section{A b s tract}

Over a 37-year period, we observed 1011 active bee nests and abandoned combs of Apis dorsata and Apis laboriosa in Nepal, India, the Philippines, and Bhutan. This article focuses on the reasons for the different shapes of the nests. We discovered that differing ambient conditions were the reasons for the following three shapes of symmetrical nests: vertical semi-ellipse, semicircle, and the horizontal semi-ellipse. We noted that asymmetrical nests were constructed when there was lack of space to extend the comb equally in both external directions. An asymmetrical nest also appeared when remnants of a previous comb remained on one edge of the nest. Convex nests were constructed to avoid excess sun exposure. Concave nests appeared as a result of low temperatures during the night and part of the day (Nepal). An L-shape nest was constructed when there was lack of space available to extend the nest in a straight direction. The shape of the nests also determines the way the combs fall.

Keywords: $A$. dorsata , A. laboriosa, bee nests, nest shape, Megapis

\section{INTRODUCTION}

The giant bee, Apis dorsata, and the cliff bee, Apis laboriosa, belong to the subgenus Magapis. The nest dimensions of the Apis dorsata and Apis laboriosa have been measured. Surprisingly though, almost nothing has been published about the shape of the nests.

In the Philippines, Morse \& Laigo (1969) measured the dimensions of 21 nests of Apis dorsata breviligula. Most of the nests were close to the ground. Other reports dealt with the nests of Apis dorsata or Apis laboriosa on high arboreal or terrestrial supports. Deodicar et al. (1977) measured the dimensions of 1861 nests of Apis dorsata distributed throughout central and western India. The dimensions of 140 colonies near Bangalore, India were measured by C. C. Reddy (1983). The dimensions of 673 active bee nests around Bangalore were measured by M. S. Reddy (1988). In addition to the dimensions, he also presented drawings of 10 shapes of 1370 observed nests. The majority of the nests were symmetrical. A minority was asymmetrical. The author did not mention whether the nest surface was flat or uneven. More nest dimensions were measured by Kumar \& C. C. Reddy (2003) at 45 nest sites in and near Bangalore. Woyke et al. (2005b and 2007) measured the dimensions of combs in colonies in which the colonies had remained for a determined period after arriving. In this paper we have tried to explain why the different shapes of the nests occur and when the different shapes arise.

\section{MATERIAL AND METHODS}

The data were collected over a 37-year period; from 1972 (India) to 2008 (Bhutan). We often used data and figures collected in India: (1972, 1974 (both see Tab. 1), Woyke et al. 2005a, 2005b, 2007, in Vietnam: 1996, in Nepal: 1998 
Table 1.

\section{Characteristcs of investigated Apis dorsata nests in different localities during 1972 - 2008 (37 years).}

\begin{tabular}{|c|c|c|c|c|}
\hline Location & Year & No sites & No nests & References \\
\hline \multicolumn{5}{|c|}{ India 1972, 1974} \\
\hline 1 Benares & 1972 & 1 & 2 & \\
\hline 2 Poona & 1974 & 3 & 4 & \\
\hline 3 Mysore I & 1974 & 1 & 68 & \\
\hline 4 Bandipur Nat. Park & 1974 & 1 & 11 & \\
\hline Total India & $1972-74$ & 6 & 85 & \\
\hline \multicolumn{5}{|c|}{ Vietnam, Delta of Mekong River 12-13.10.1996 } \\
\hline $\begin{array}{l}5 \text { Song Trem farm } \\
\text { Total Vietnam }\end{array}$ & 1996 & 3 & 8 & $\begin{array}{c}\text { Woyke (1997) Rafter beekeeping } \\
\text { http://jerzy_woyke.users.sggw.pl/1997_ } \\
\text { gospod_krokw_rafter.pdf }\end{array}$ \\
\hline \multicolumn{5}{|c|}{ Nepal, Chitwan National Park and Bharatpur 20-28.03.1998. } \\
\hline 6 Chitwan Nat. Park & 1998 & 4 & 12 & \\
\hline 7 Bharatpur & 1998 & 1 & 7 & \\
\hline \multicolumn{5}{|c|}{ Nepal 14.10-27.10 1999 and 04.01-11.01 2000} \\
\hline 8 High tower & $1999 / 2000$ & 1 & 65 & \multirow{7}{*}{$\begin{array}{c}\text { Woyke et al. (2001) Swarming, migration } \\
\text { and absconding of Apis dorsata colonies. } \\
\text { http://jerzy_woyke.users.sggw.pl/2001_ } \\
\text { dorswarmchm.pdf } \\
\text { Woyke et al. (2003b) Flight activity } \\
\text { http://jerzy_woyke.users.sggw.pl/2003_ } \\
\text { flight_activity_meldorlab.pdf } \\
\text { Woyke et al. (2004) Periodic mass flights } \\
\text { http://jerzy_woyke.users.sggw.pl/2004_ } \\
\text { dopmfs.pdf }\end{array}$} \\
\hline 9 Low tower & 1999/2000 & 1 & 17 & \\
\hline 10 House 1 & 1999/2000 & 1 & 18 & \\
\hline 11 House 2 & 1999/2000 & 1 & 13 & \\
\hline 12 Maize Institute & 1999/2000 & 1 & 7 & \\
\hline 13 Bharatpur tower & 1999/2000 & 1 & 12 & \\
\hline Total Nepal & 1999/2000 & 11 & 151 & \\
\hline \multicolumn{5}{|c|}{ India 03-13.03.2002, and 20.10-03.12.2005 } \\
\hline $\begin{array}{l}15 \text { Bangalore, } \\
\text { banyan tree }\end{array}$ & 2002 & 1 & $\begin{array}{c}159 \\
*(98+61)\end{array}$ & $\begin{array}{c}\begin{array}{c}\text { Woyke et al. (2005b) Periodic mass flights } \\
\text { of the giant honeybee. } \\
\text { http://jerzy_woyke.users.sggw.pl/ } \\
\text { dopmfsuccdays.pdf } \\
\text { Woyke et al. (2007) Presence or absence } \\
\text { of drones } \\
\text { http://jerzy_woyke.users.sggw.pl/ } \\
\text { dordrondusk.pdf }\end{array}\end{array}$ \\
\hline 16 Bangalore, Polyt. & 2005 & 1 & 4 & \multirow{5}{*}{$\begin{array}{c}\text { Woyke et al. (2007) Presence or absence } \\
\text { of drones in drone dusk mass flights } \\
\text { performed by Apis dorsata foragers. } \\
\text { http://jerzy_woyke.users.sggw.pl/ } \\
\text { dordrondusk.pdf }\end{array}$} \\
\hline 17 Agricultural Uni. & 2005 & 1 & 4 & \\
\hline $\begin{array}{c}18 \text { Banyan tree } \\
\text { Ramagovindapura }\end{array}$ & 2005 & 1 & 250 & \\
\hline Mysore II & 2005 & 1 & 53 & \\
\hline Total India & 2002,2005 & 6 & $\begin{array}{c}498 \\
437+61\end{array}$ & \\
\hline \multicolumn{5}{|c|}{ The Philippines 27.02-06.03.2004 } \\
\hline 19 Los Banios & 2004 & 1 & 1 & \multirow{6}{*}{$\begin{array}{l}\text { Woyke et al. (2005a) Workers often pre- } \\
\text { dominate in dusk drone flights } \\
\text { http://jerzy_woyke.users.sggw.pl/ } \\
\text { drflightjapicr2005.pdf } \\
\text { Woyke et al. (2008) Compa-rison of } \\
\text { defense body move-ments } \\
\text { http://jerzy_woyke.users.sggw.pl/2008_ } \\
\text { def_body_mov.pdf }\end{array}$} \\
\hline 20 Vulcano & 2004 & 1 & 2 & \\
\hline 21 Cagbalute Island & 2004 & 2 & 2 & \\
\hline 22 Alfonso & 2004 & 1 & 1 & \\
\hline Total Philippines & 2004 & 5 & 6 & \\
\hline Overall A. dorsata & $1972-2004$ & 31 & $748(687+61)$ & \\
\hline
\end{tabular}

* numbers in parenthesis indicate active colonies and recently abandoned combs, respectively. Shapes of nests listed in the table above are also presented in the paper by Woyke et al. (2012a). 
and 1999 (see Tab. 2), Woyke et al. 2001a, 2001b, 2003a, 2003b, 2004, 2005a 2005b, in the Philippines: 2004 and in Bhutan: 2012a, 2012b), while investigating other problems of $A$. dorsata and $A$. laboriosa biology.

We investigated a total of 29 locations with 50 nesting sites on which 1011 colonies of $A$. dorsata and $A$. laboriosa had nested. There were 925 active nests, and 86 recently abandoned combs. Apis dorsata occupied 31 nesting sites on which 748 colonies had nested. From those colonies, there were 687 active nests and 61 recently abandoned combs (Tab. 1).

Apis laboriosa occupied 19 nesting sites on which 263 colonies had nested. Of those, 238 were active nests and 25 were recently abandoned combs (Tab. 2).

Previously, the reason why a particular shape of comb or nest occurred was not explained. We provide what we believe is a logical explanation for this phenomenon drawn on the basis of particular shapes of nests found in specific ambient conditions.

Some descriptions were necessary to verify our conclusions.

\section{RESULTS}

\section{Flat nests}

\subsection{Index of nest shape}

We developed a new tool to describe and compare the shape of the nests. We named this tool "the nest shape index" (NSI). This index shows the ratio of the horizontal dimension of the attached base of the nest, to the vertical dimension measured from the middle of the horizontal dimension to the lower end of the nest (Fig. 1).

There are three shape-types of symmetrical A. dorsata nests: 1./ the vertical semi-ellipse; nest shape index (NSI) < 2.0, (Fig. 2), 2./ the horizontal semi-ellipse NSI > 2.0, (Fig. 3), and 3./ the semicircle nests; NSI = about 2.0 (Fig. 4c). The nests of $A$. dorsata in terrestrial wind-protected locations were vertical semiellipses; $\mathrm{NSI}=$ mean 1.4, range $1.0-1.5(n=9)$, (Fig. 1 ). Under branches of trees with leaves, some nests were semi-circles; NSI = mean 1.1, range $1.0-1.2$ ( $n=5$, Fig. 4c). In windy open places, like under branches of trees without leaves, the nests were horizontal semi-ellipses, NSI = 3.3-4.7 (Fig. 3).

For Apis laboriosa, the mean NSI $=0.96$ and the variation ranged from 0.80 to $1.17(n=15)$, (Fig. 5). All the nests were deep vertical semiellipses. The nests of $A$. laboriosa were built beneath overhangs, close to the vertical wall of the cliff. The wind could not blow through the nests and break them off. This is probably the reason that the bees were able to extend their nests vertically.

We came to the conclusion, that different environmental conditions are the reasons the nest shapes varied. On arboreal supports, the wind blows through and easily breaks a vertically shaped nest, while it is difficult for the wind to break a nest, which has a horizontal shape. On terrestrial supports, the wind is unable to blow through as much; therefore, the nests may be of a vertical shape. Since the cliff blocks the wind, the $A$. laboriosa nest can be a vertical semi-ellipse.

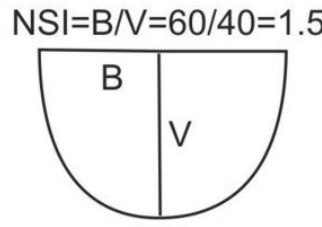

Vertical semi-ellipse

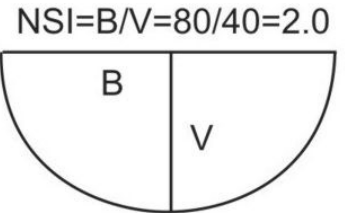

Semi-circle
$\mathrm{NSI}=\mathrm{B} / \mathrm{V}=100 / 40=2.5$

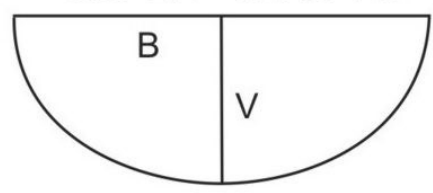

Horizontal semi-ellipse

Fig. 1. Nests of different shapes. B - base dimension, V - vertical dimension, $\mathrm{NSI}$ - nest shape index. NSI=B/V. NSI<2 - the nest is a vertical semi-ellipse, $\mathrm{NSI}=2$ - the nest is a semi-circle , $\mathrm{NSI}>2$ - the nest is a horizontal semi-ellipse. 
Characteristics of observed Apis laboriosa nests in different localities during 1998 - 2008 (within 11 years).

\begin{tabular}{|c|c|c|c|c|}
\hline Location & Year & No sites & No nests & References \\
\hline \multicolumn{5}{|c|}{ Nepal 28.03.1998 and 27.11-02.12 and 05-06.12.1999 } \\
\hline 23 Chale & 1998 & 1 & $\begin{array}{c}57 \\
*(43+14)\end{array}$ & \multirow{4}{*}{$\begin{array}{c}\text { Woyke et al. (2001) A scientific } \\
\text { note on Apis laboriosa winter } \\
\text { nesting and brood rearing in the } \\
\text { warm zone of Himalayas. } \\
\text { http://jerzy_woyke.users.sggw.pl/ } \\
\text { lawintnest.pdf }\end{array}$} \\
\hline 24 Kodari & 1998 & 1 & $\begin{array}{c}5 \\
(4+1)\end{array}$ & \\
\hline 25 Totapani & 1998 & 1 & 14 & \\
\hline 26 Chale & 1999 & 1 & $\begin{array}{c}57 \\
(53+4)\end{array}$ & \\
\hline 27 Kodari & 1999 & 1 & $\begin{array}{c}8 \\
(6+2)\end{array}$ & \multirow{3}{*}{$\begin{array}{c}\text { Woyke et al. (2003a) Periodic mass } \\
\text { flights of Apis laboriosa in Nepal. } \\
\text { http://jerzy_woyke.users.sggw.pl/lapmf. } \\
\text { pdf }\end{array}$} \\
\hline 28 Totapani & 1999 & 1 & $\begin{array}{c}13 \\
(10+3)\end{array}$ & \\
\hline 29 Annapurna & 1999 & 1 & $\begin{array}{c}17 \\
(16+1)\end{array}$ & \\
\hline Total Nepal & 1998-1999 & 7 & $171(146+25$ & \\
\hline \multicolumn{5}{|c|}{ Bhutan 22-25.09.2008 } \\
\hline Total Bhutan & 2008 & 12 & 92 & $\begin{array}{c}\text { Woyke et al. (2012b) Which } \\
\text { mountain cliffs do, } \\
\text { A. laboriosa select } \\
\text { http://jerz_woyke.users.sggw.pl/2012 } \\
\text { laboriosa_nesting_sites.pdf }\end{array}$ \\
\hline Overall A. laboriosa & $\begin{array}{c}1998-1999 \\
2008\end{array}$ & 19 & $263(238+25$ & \\
\hline
\end{tabular}

* numbers in parenthesis indicate active colonies and recently abandoned combs, respectively. Shape of nests listed in the table above are also presented in the paper by Woyke et al. (2012a).

\subsubsection{Does the shape of symmetrical combs change as the nests grow?}

The average size of 3 combs on a balcony in Bangalore (Fig. 7) one week after the arrival of the swarms was $35 \times 25 \mathrm{~cm}$ (Woyke et al. 2005b, 2007). The comb shape index (CSI) was 1.4 , indicating a vertical semi-ellipse shape. One month later, the size of the combs increased to $75 \times 60 \mathrm{~cm}$, and the $\mathrm{CSI}=1.3$. The size of the combs did not increase more, and eight months later the CSI $=1.4$. This indicates, that in terrestrial nesting sites, the shape of combs up to a size of $75 \times 60 \mathrm{~cm}$ does not change. As the nectar flow continues, though, the size of the nests increases and the shape changes.

We have no photos of the early-stage shape of those combs or nests, which later evolved into horizontal semi-ellipses. Figure 4 shows that vertical dimensions of fully developed circular, vertical, and horizontal semi-ellipses nests are similar. It seems, that after reaching a maximal vertical dimension of about $1 \mathrm{~m}$, further growth of the comb takes place only in a horizontal direction. The consequence is, that horizontal semi-ellipse nests are larger than vertical ones. This results in higher honey harvests from horizontal semi-ellipse nests.

\subsection{Asymmetrical nests}

In the asymmetrical nests, one-half (e.g. the right one) is differently shaped than the other half (Fig. 6). One half of the nest is elongated with a pointed upper-outside corner, while the other half is shorter with a blunt upper-outside 


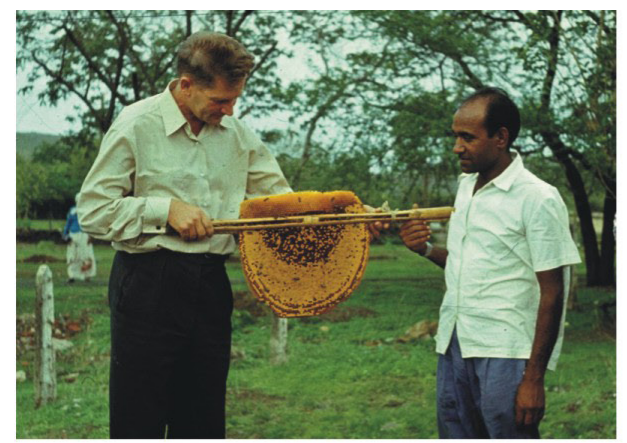

Fig.2. Vertical semi-ellipse comb of A. dorsata, CSI=1,0, Poona, India 1974

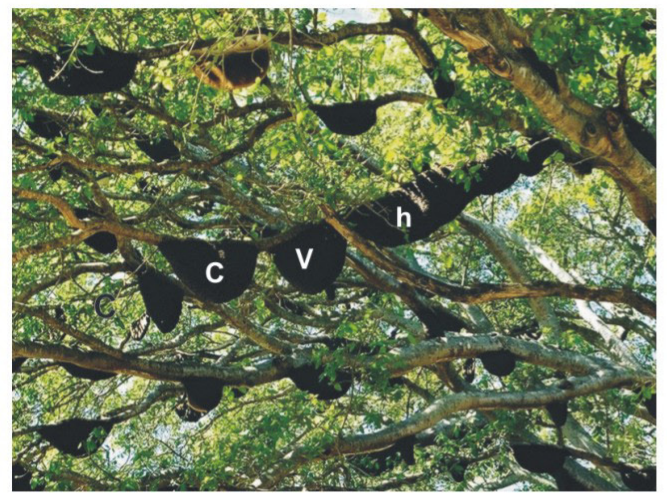

Fig. 4. Semi-circle (c), vertical (v) and horziontal (h) semi-ellipse nests, Ramagovindapura, India 2005

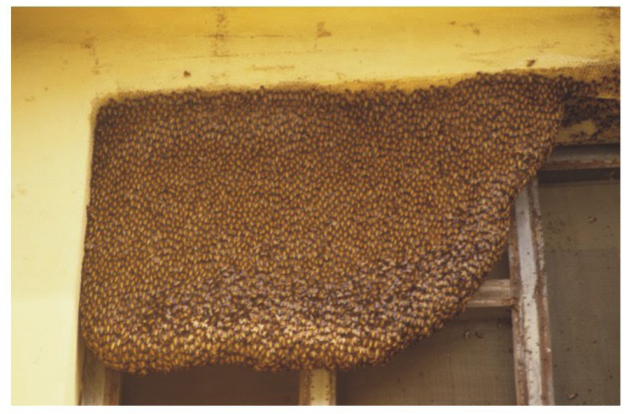

Fig. 6. Asymmetrical nest in nishe of window, Nepal 1999

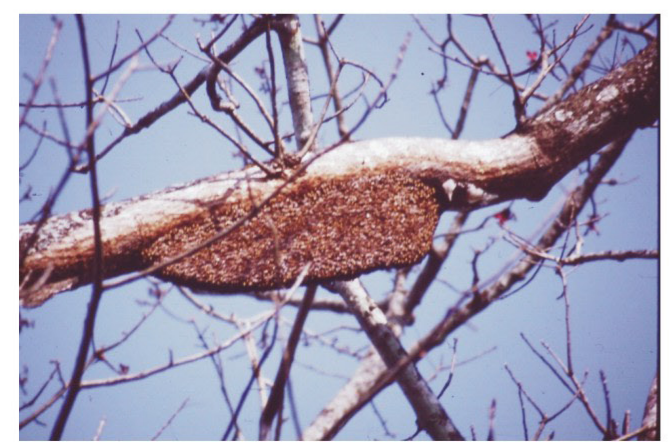

Fig. 8. Asymmetrical nest, arboreal support, Chitwan, Nepal 1998

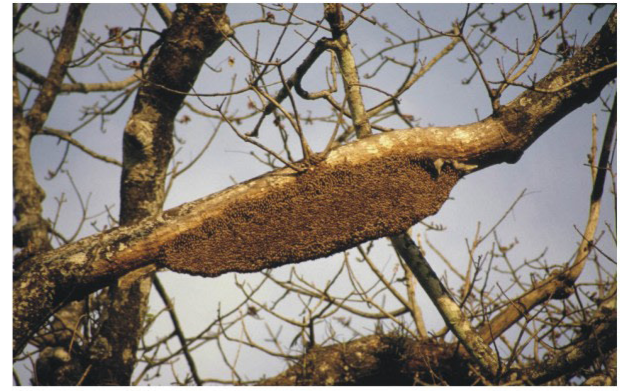

Fig. 3. Horizontal semi-ellipse nest, Chitwan, Nepal 1998

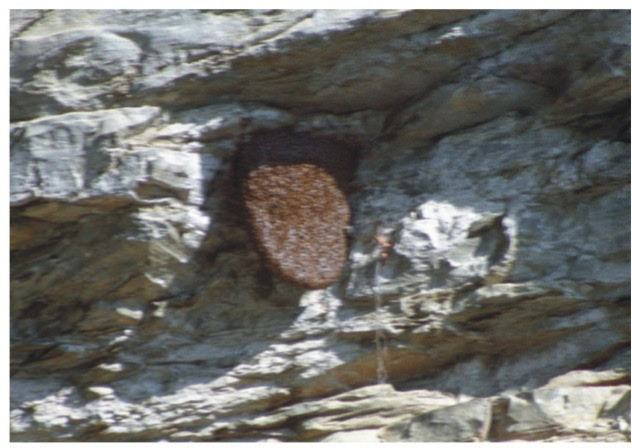

Fig. 5. Vertical semi-ellipse nest of A. laboriosa, Annapurna, Nepal 1999

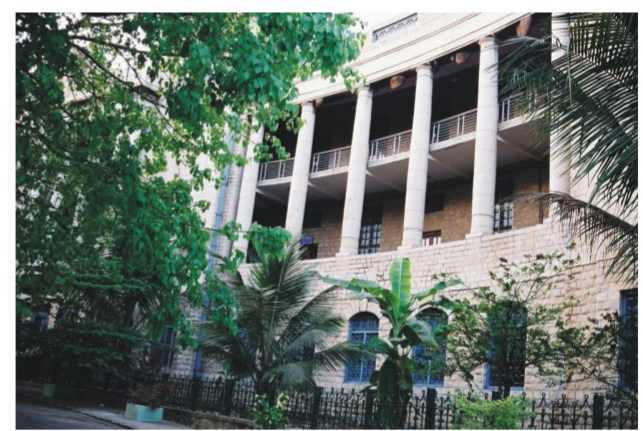

Fig. 7. Asymmetrical and convex nests on a balcony, Bangalore, India 2002

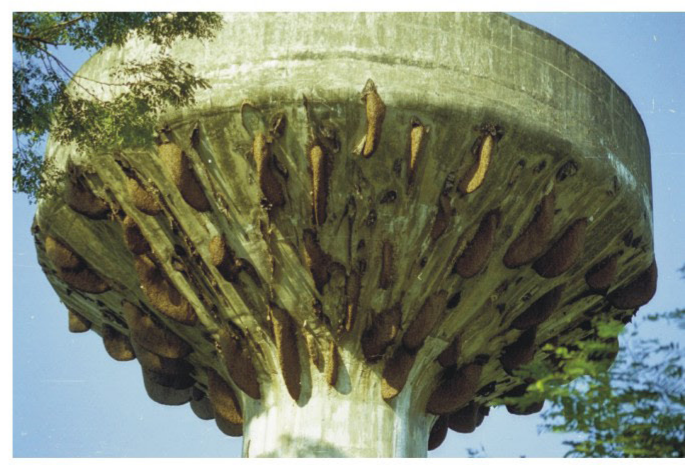

Fig. 9. Sloped nests under the water tank of the tower in Rampur, Nepal 1999 
corner. The angle between the ceiling where the nest is attached and the margin of the upper-pointed corner is sharp. This angle is less than $90^{\circ}$ and may even be less than $45^{\circ}$, while the other corner is almost a right angle (about $90^{\circ}$ ).

Asymmetrical nests were found hanging from the ceilings of terrestrial, human-made structures, i.e. buildings. We found such a nest hanging from the ceiling of a window niche in Rampur in Nepal 1999 (Fig. 6). It can be assumed that the bees started to construct the comb from the ceiling not in the middle of the ceiling, but closer to the left side. At the beginning, the comb was symmetrical. As the bees extended the comb in both external directions, they reached the left margin of the niche. They could no longer extend the comb further in this direction. However, they could extend the comb in the opposite direction. As a result, the left upper corner of the comb became blunt and the right one became pointed.

This shows, that the reason a nest appears asymmetrical is because of a lack of space available to extend the nest equally in both external directions. The blunt corner appears on the side where the extension of the comb is hindered, and the pointed corner appears where the extension has taken place.

We also found asymmetrical nests on arboreal nesting sites. Such a nest was noted under a branch of a tree in Chitwan National Park in Nepal (Fig. 8). The left end of the nest was sharp, and the right one was blunt. Near the right end of the nest, remnants of a comb from the prior season were present beneath the branch. The bees never construct their comb on the remnants of combs from an earlier season. This means that the remnants of a previous comb restricted the ability to extend the nest in the right direction. Thus, the remnants of a previous comb caused the asymmetrical shape of the nest.

\subsection{Nests under a sloped support}

Nests under sloped supports occur on terrestrial and arboreal nesting sites as well as under rafters. We found such nest on the terrestrial side under the water tank of the tower in Rampur, Nepal 1999 (Fig. 9). We found them also on the arboreal sides of trees in Bandipur National Park in 1974 (Fig. 10), and on Banyan trees in Bangalore in 2002 and Ramagovindapura in 2005 (Fig. 4), in India and the Philippines in 2004 (Fig. 26). We also observed such nests beneath the rafters on the Song Trem farm in the delta of the Mekong River in Vietnam in 1996 (Woyke, 1997), (Fig. 11). All the nests were asymmetrical. The lower corner of each nest was blunt, and the upper one pointed. The bees store the honey in the upper corner of the comb. The upper part, which is filled with honey, can be cut up without destroying the nest. This way, the honey can be harvested several times without damaging the nests.

The nest shape is based on what the incline of the rafter is. Under $30^{\circ}, \mathrm{NSI}=3.11$ and under $45^{\circ}, \mathrm{NSI}=2.00$. This means that if there is a low incline of the rafter, the attachment base is 3 times longer than the vertical dimension, and if there is a high incline, the base is only two times higher than the vertical dimension. If there is a higher incline, the horizontal dimension of a nest is lower and the nest is narrower.

\section{Irregular nests}

Nests, which are not flat and straight, are considered irregular.

\subsection{Convex nests}

We found convex nests in Bangalore, in 2002 (Woyke et al. 2005a, b). The nests were attached to the ceiling of the south and east balcony of the Polytechnic building. The combs were constructed beneath the support beams. The beams were between the columns of the balconies (Fig.12).

The middle part of the comb of the nest was constructed parallel to the external edge of the beams. However, the left and right extreme parts of the comb curved towards the inside of the balcony (Figs 12 and 13). At the south 


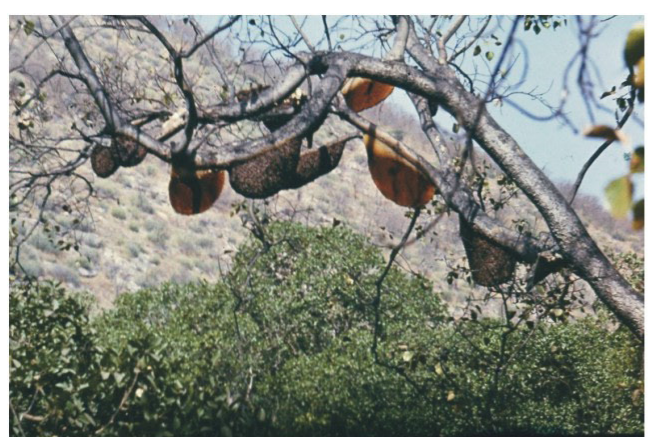

Fig. 10. vertical and horizontal semi-ellipse nests, Bandipur 1974

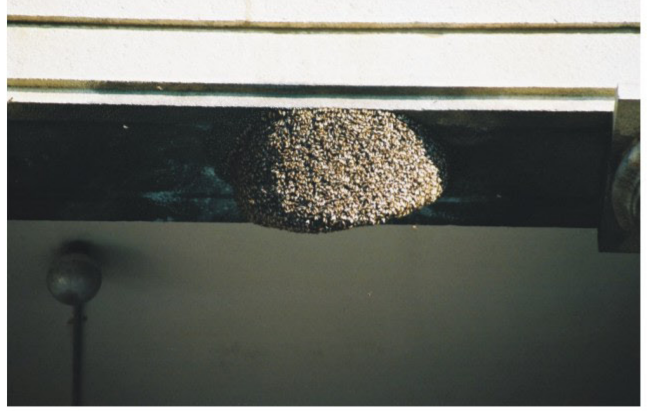

Fig. 12. Convex nest, Bangalore, India 2002

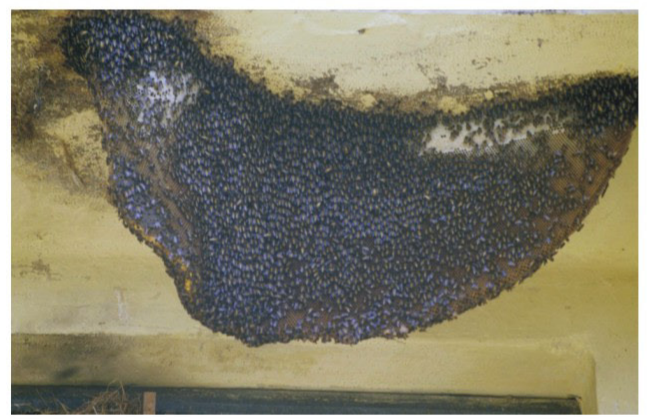

Fig. 14. Concave nest, Rampur, Nepal 2000

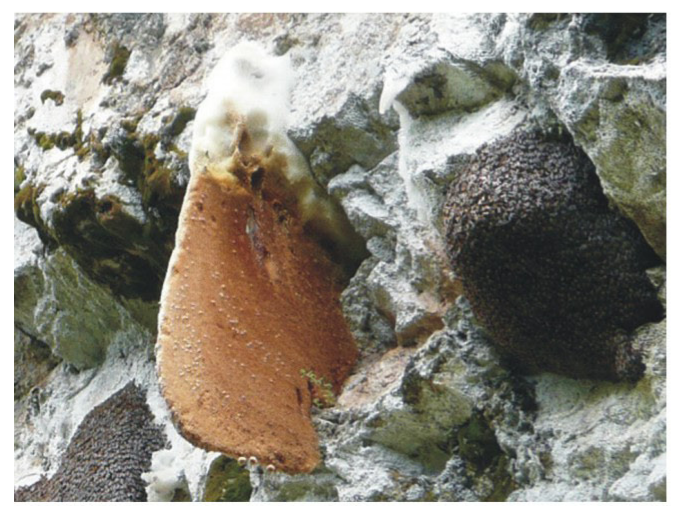

Fig. 16. Upper part of $A$. laboriosa comb built over the ceiling, Bhutan 2008

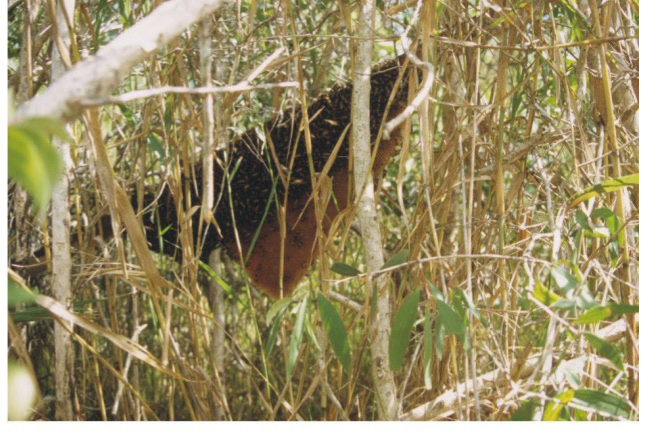

Fig. 11. Nest under sloped rafter in swamp of Mekong River, Vietnam 1996

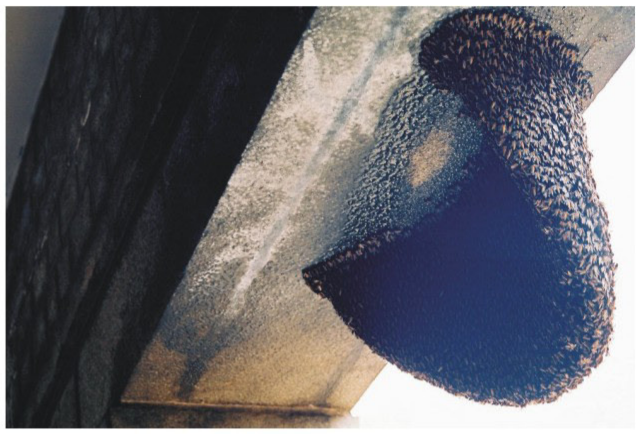

Fig. 13. Insign view of convex nest, Bangalore, India 2002

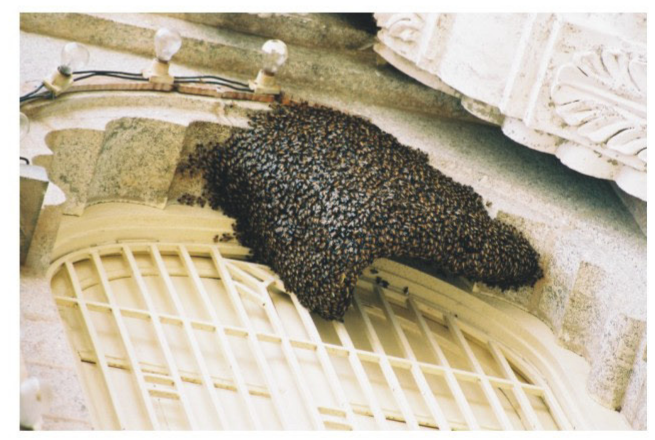

Fig. 15. L-shaped nest, Mysore, India 2005

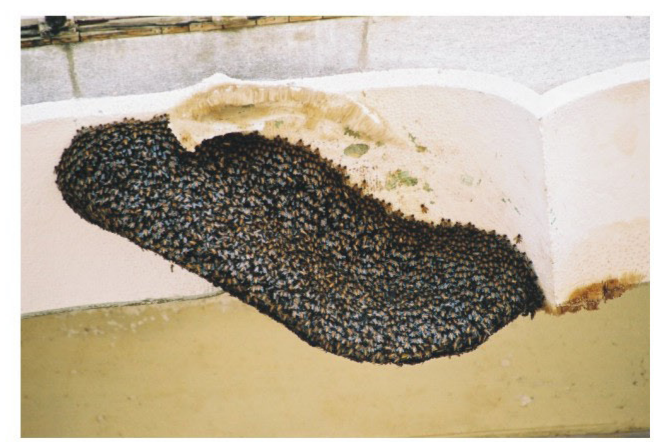

Fig. 17. Wavy nest, Mysore, India 2005 
balcony, the bent parts of the comb faced north. At the same time, at the east balcony, the bent comb-parts faced toward the west. When the sun was shining, it lit the middle part of the comb, but the curved parts of the comb were hidden in the shade.

One would think that the bees would have started to build the combs parallel to the external edges of the beams. However, when the temperature rose to $40^{\circ} \mathrm{C}$ or more, the bees tried to hide themselves and the combs in the shade; deeper towards the inside of the balcony (Figs 12 and 13).

\section{2. Concave nests}

Concave nests had both of its extreme parts curved toward the outside of the building. In the period from 1999 to 2000, we found such nests in terrestrial buildings in Nepal in the Chitwan district in Rampur on the campus of the Tribhuvan University (Fig. 14). The swarms were arriving to Chitwan from October until December (Woyke, Wilde \& Wilde, 2001b). At the beginning of the season (October) the temperature is high, but as the season progresses, the temperature steadily drops. During the day the bees can forage, but at night the temperature drops in November to $16-17^{\circ} \mathrm{C}$ and the bees become chilled (Woyke, Wilde \& Wilde, 2003b and Woyke et al., 2004). The morning sun warms the bees and foraging starts at about 11 a.m. We noted that $A$. cerana and $A$. mellifera bees started foraging several hours earlier.

It may have seemed that the bees would have started constructing the comb parallel to the external edge of the niche of the window. Instead, while it was cool, the bees constructed the rest of the comb in the direction of the sun. They did this to keep themselves warm and to facilitate the building of the comb.

Thus, the heat causes the nests to become convex, and the cold causes the nests to become concave.

\subsection{L-shaped nests}

L-shaped nests are not straight, but they are bent at a $90^{\circ}$ angle. The horizontal cross of these nests is an L-shape. We found an L-shaped $A$. dorsata nest on the Maharaja's palace in Mysore 2005 (Fig. 15). The nest was hanging from the ceiling of a window niche. One part of the nest crossed the ceiling of the niche perpendicular to the surface of the palace wall. The rest of the nest was along the external edge of the niche. It is assumed that the bees started to construct the comb of the nest in the niche, in a direction perpendicular to the surface wall of the building. When they soon reached the external edge of the niche, they could only extend the comb in an L-shape along the edge of the niche. As a result, the L-shaped nest appeared. Thus, the reason for the appearance of an L-shape nest was the lack of space to extend the comb in a straight direction.

\subsection{Part of the nest over the ceiling}

We investigated $A$. laboriosa in the Himalayas, in Nepal in 1999 (Woyke, Wilde \& Wilde, 2001a). We never found L-shaped nests built by A. laboriosa. However, some colonies also constructed combs perpendicular to the wall in a niche beneath the overhang of the cliff. When the comb grew upwards from underneath the overhang, and reached the outside edge of the overhang, the bees did not bend it upwards to continue constructing it along the edge. Instead, $A$. laboriosa bees extended the comb to the outside surface above the ceiling of the cliff overhang (Fig. 16).

\subsection{Wavy nests}

We found an irregularly shaped nest in 2005, at the Maharaja's palace in Mysore (Fig. 17). The horizontal cross-section was wavy. Evidently, the new swarm of bees started to construct the comb near the remnants of a previous colony's convex comb. The new swarm of bees did not include these remnants in their combs. As a result, they had to construct an irregular 
comb. It may be concluded, that remnants of a previous colony's comb may force bees to construct a wavy comb; which results in a wavy nest.

\subsection{Nests with 2 combs}

New swarms were arriving to Rampur, Nepal, in October and November 1999. At that time, many small white combs of $20 \times 30 \mathrm{~cm}$ appeared (Fig. 18). It turned out, that some new swarms stayed for few days only. They built small white stopover combs, which remained after the swarms emigrated. It happened that several times that the next arriving swarms settled on the site of the small white stopover comb. The arriving bees did not occupy the small comb. Instead, they constructed their own comb on the side of the small one. The new nest enlarged, but the bees did not occupy the small white comb. After some time, the nest was enlarged and the curtain bees gradually covered the small, white comb. Finally, the curtain bees covered the whole small comb forming a nest with two combs. Unfortunately, we do not know whether the bees accepted the small comb as their own and stored honey and reared brood in it. Preliminary observations suggest that the bees do not accept the stop-over combs as their own.

\section{The shape of a nest determines the way an abandoned comb fall from the support 3.1. Why and when do the abandoned combs fall?}

In Bangalore, on 3 March 2002, on a banyan tree, there were 98 active colonies, 45 empty abandoned combs, and 16 remnants of fallen combs. Eight of the 21 empty combs had between 1 to 9 remnants of queen cells. Evidently, some colonies had swarmed out, and others emigrated. Six swarms emigrated in our presence. Five more emigrated within two days after the end of the observations (13 March). While some colonies emigrated others still remained on the tree. The bees emigrated after all healthy brood emerged, and the honey was consumed.

The combs fell down not long after the bees emigrated, but when most of the other nests were still active on the tree. We collected 9 combs, which had fallen to the ground (Fig. 19). They were not damaged by the wax moth (Fig. 20). It was evident that the combs had not fallen down months after the bees abandoned them, but rather, had fallen several days after the bees left them. We never found fallen combs with brood and honey.

Clothes drying on a line may explain this phenomenon. The wind manages to move heavy wet clothes just a little. In contrast, the wind can blow dry light linen 90 degrees.

A similar phenomenon may occur with the combs. The temperature in the nest is about $34^{\circ} \mathrm{C}$. The outside temperature, especially at night, is lower.

The average daily temperature during the observation time was $28.8^{\circ} \mathrm{C}$ (Woyke et al. 2005b). The average monthly high temperature in March in Bangalore is $33^{\circ} \mathrm{C}$ and the avg. low temp. is $20^{\circ} \mathrm{C}$ (see, Bangalore Monthly Climate Average). The maximal and the minimal temperatures may be higher and lower, respectively. The difference between the nest temperature $\left(34^{\circ} \mathrm{C}\right)$ and low ambient temperatures $\left(20^{\circ} \mathrm{C}\right)$ is $14^{\circ} \mathrm{C}$.

At a lower temperature, the wax walls of the cells become brittle and can easily break. A light wind may break them, and the combs fall. To sum up, an outside temperature that is lower than the temperature inside the nest causes the wax cells to become brittle and breakable, and the combs are easily broken by the wind.

\subsection{Why does a whole empty comb rather than part of a comb fall down?}

The comb cell-walls within the brood area аге lined with several layers of cocoons of the brood. Bee brood had been reared in the cells. The walls of such cells are thick, and the brood comb area is flexible. The color of the brood cells changes from white to brown. However, the bees store 
honey at the upper part of the comb. After the honey is consumed, the white pure-wax cells remain (Fig. 21). When the night temperatures are low, the upper part of the comb becomes brittle and breakable. Even a light wind can break the upper part and the whole comb falls down. Thus, the pure-wax cells at the upper part of the comb cause the entire comb to fall. The nest shape index of a fallen comb was 1.4 (Fig. 20). The other fallen combs had a similar shape. This means the combs, and the nests were vertical semi-ellipses. Abandoned combs of a vertical semi-ellipse shape are more susceptible to breakage by the wind than semi-circles or horizontal semi-ellipses.

\subsection{Why do remnants of some combs remain on the nesting place?}

When the nectar flow is low, the bees eat the stored honey from part of the white cells near the upper attachment of the comb. The queen lays the eggs in those cells, and the larvae spin the cocoons in them. After worker bees emerge, the cocoons remain in the cells. The upper attached part of that comb is not white but brown, and it is not fragile (Fig. 22). At low temperatures, when the wind blows, the upper white fragile part of the comb is broken, but a fraction of the upper brown part of the comb remains under the support. Thus, remnants of some combs remain on the support, because bee brood had been reared in the cells up to the attached base, making that part of the comb flexible and unbreakable.

\subsection{Why do the convex and curved combs remain in place longer?}

In Bangalore, India, in 2005, we found convex or curved combs, which had survived long after the bees emigrated. The comb in Fig. 23 had been damaged by pests, and it was obvious that the comb had remained in place for a long time.

The reason that concave or convex combs remain in place longer is that they cannot be twisted or bent by the wind. As a result, the upper pure-wax cells are not crushed and the combs remain in place.

\subsection{The reasons why a particular comb did not fall down}

Wax moth activity is visible on the comb pictured in Fig. 24. It is evident that the comb remained in the tree a long time after the bees had emigrated. Why is it that the comb did not fall down? There are three reasons. The comb nest index $(\mathrm{CNI})=3.3$, indicating that the comb is a long horizontal ellipse. Such long combs are not prone to wind damage. The comb is curved and curved combs are resistant to breakage by wind. Brood was reared in the part of the cells at the attached base of the comb, which makes the cells resilient to damage by wind.

\subsection{Why some abandoned combs survive to the next season?}

In 1999, in Rampur, Nepal, we found two combs in which the brood area was eaten by wax moths. The moth web completely covered that part of the comb (Fig. 25). At that time, new swarms were arriving. It was obvious, that the two combs had survived from last season. Why did they not fall? The combs were constructed in a deep niche under the roof of the house. No wind was blowing there. The lack of wind kept the combs from breaking and falling.

\section{DISCUSSION}

Up till now, only M. S. Reddy (1988) has described the different nest shapes of $A$. dorsata bees. He presented small drawings of 10 nest shapes. He did not suggest the reasons for different nest shapes, except vertical and horizontal nests. He writes: "Greater length (vertical dimension) of combs of terrestrial colonies and higher breadth (horizontal dimension) of the combs of arboreal colonies are greatly due to the varying degrees of rigidity of the support. Rigid supports of buildings bear the greater length (vertical dimension) of the combs, while the flexible support of trees allows greater horizontal growth." Reddy's results are 


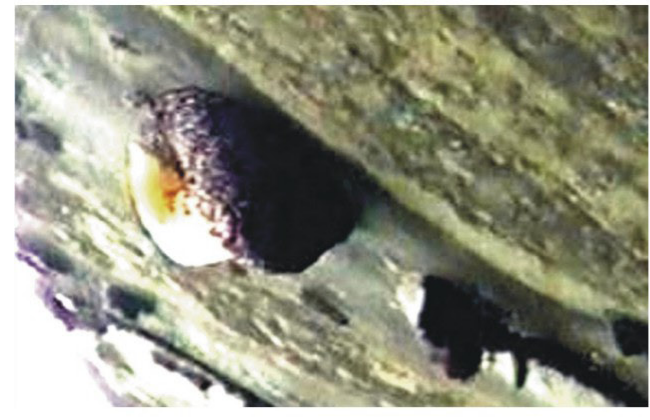

Fig. 18. Smal white stopover comb near a nest, Rampur, Nepal 1999

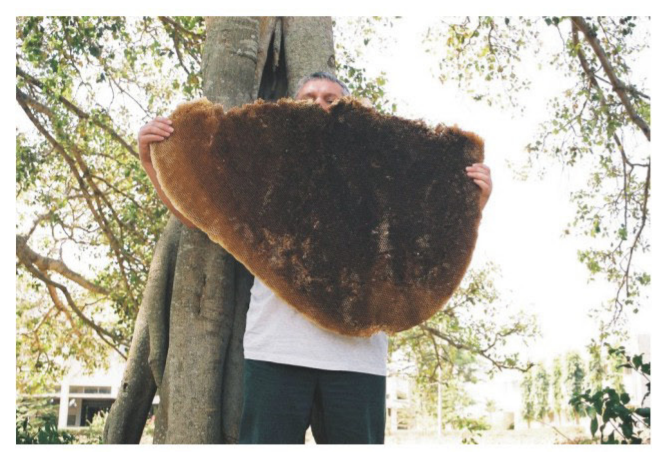

Fig. 20. The follen comb shows no demage from the wax moth, Bangalore, India 2002

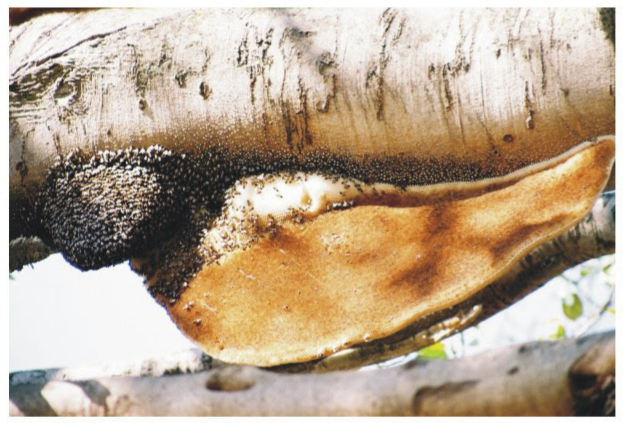

Fig. 22. Upper white part of the comb is breackable, while the brown one is flexible

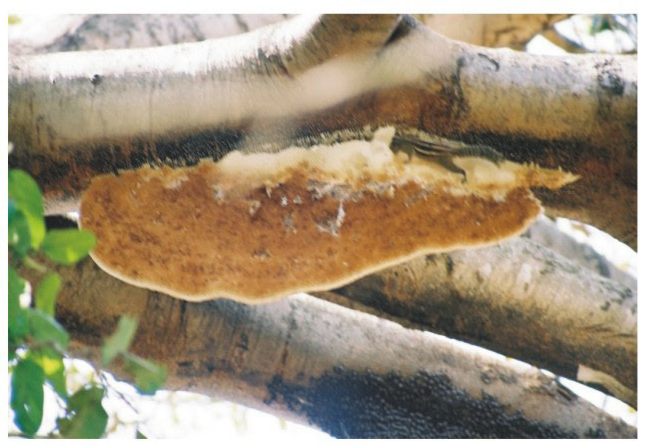

Fig. 24. Curved horizontal nest $\mathrm{CSI}=3.3$ remains longer at the place

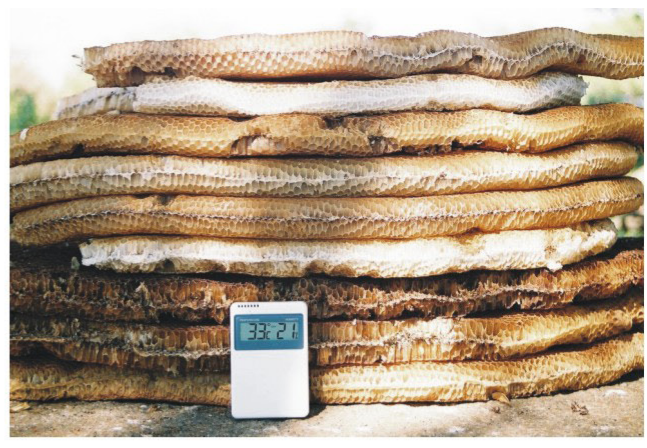

Fig. 19. Fresh combs fallen from the tree,

Bangalore, India 03. 2002

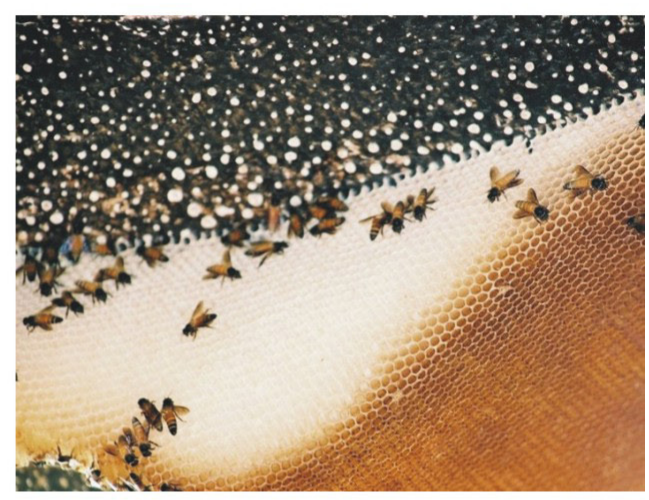

Fig. 21. The upper part of an abandoned comb cosists of wite pure-wax cells wtout cocoons

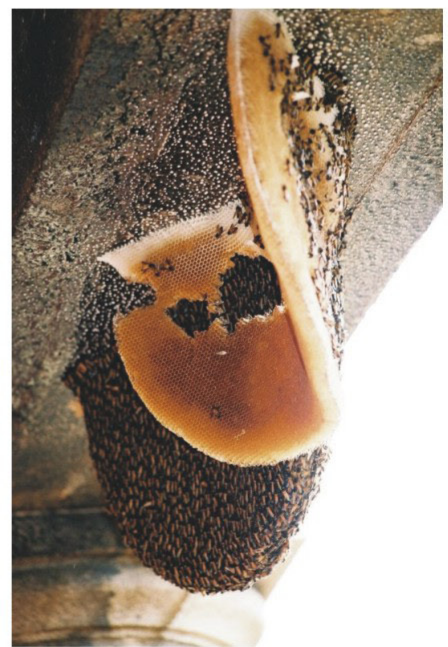

Fig. 23. Convex abandoned comb remains longer at the place,

Bangalore, India 2002 


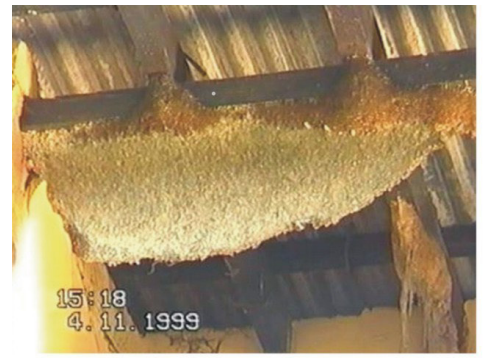

Fig. 25. Comb from previous season. Rampur, Nepal 1999

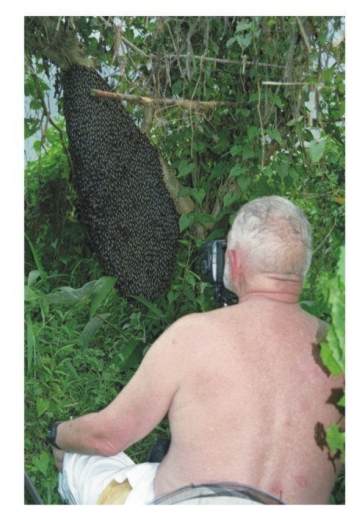

Fig. 26. Vertical semi-ellipse nest of $A$. $d$. breviligula under a sloped flexible branch near the ground. The Phillipines 2004 similar to ours; we found that nests on terrestrial supports are vertical semi-ellipses; NSI $<2$, while in arboreal supports, the nests are semi-circles, NSI $=2$ or horizontal semi-ellipses $\mathrm{NSI}>2$. However, our explanation of such shapes of nests on terrestrial and arboreal supports does not concern the rigidity of the supports. Our conclusion in Section 3.1.1. was, that environmental conditions are the reason there are different shapes of symmetrical nests. On arboreal supports, the wind blows through and easily breaks vertically-shaped nests, while it is difficult to break horizontally-shaped nests. On terrestrial supports, the wind is unable to blow through as much, which means the nests may be of a vertical shape.

Of the 21 nests measured in the Philippines by Morse \& Leigo (1969), 19 were from $12 \mathrm{~cm}$ up to $1.5 \mathrm{~m}$ above the ground. The next two were $4 \mathrm{~m}$ and $10 \mathrm{~m}$ above the ground. Most of the nests were near the ground in the deep tropical forest. We calculated the nest shape indexes of these nests (NSI). The nest shape index of one nest, $12 \mathrm{~cm}$ above the ground was 2.5, indicating a horizontal semi-ellipse. The nest was probably a horizontal semiellipse because the bees could not extend it vertically. The index of all the other 20 nests varied; $\mathrm{NCl}=0.5-1.9$, indicating vertical semiellipses. Hence, despite the fact that the nests were in flexible arboreal supports, they were not horizontal semi-ellipses as suggested by $M$. S. Reddy (1988). The environmental conditions near the ground in a deep forest are similar to terrestrial supports since there is a lack of wind blowing through.

The nests investigated by us in 2004, in the Philippines (Woyke at al., 2008) were on small trees beneath flexible branches near the ground. They were vertical semi-ellipses (Fig. 26).

The above information shows that the nests were vertical semi-ellipses. This is in agreement with our explanation according to which, the environmental conditions determine the shape of the nests (vertical or horizontal semi-ellipses). According to M. S. Reddy (1988), 81\% of the arboreal nests were symmetrical, and 19\% were asymmetrical. He also stated that 76\% of the terrestrial nests were symmetrical, and $24 \%$ were asymmetrical. However, he did not suggest why some nests are symmetrical and the others are asymmetrical.

In the scientific literature, we did not find descriptions of convex and concave nests. We also did not find reports on L-shaped or waved nests.

We found that two-comb nests appeared, because curtain bees of a side nest covered the small, white stop-over comb. Morse \& Laigo (1969) also described a nest with two combs. However the origin of the multiple-comb-nest was not explained.

Up till now, nobody has suggested why whole abandoned combs fall down rather than falling down in parts.

The final conclusions are as follows:

Different ambient conditions are the reasons 
for the different nest shapes:

1. Symmetrical nests of $A$. dorsata are of three main shapes: vertical semi-ellipse, semicircle, and horizontal semi-ellipse. Different environmental conditions are the reasons for the differences. In wind-protected conditions the nests have the shape of a vertical semi-ellipse or semicircle, and in locations without wind protection, the shape is a horizontal semi-ellipse.

The shape of $A$. laboriosanests is a deep vertical semi-ellipse. Those nests are built beneath the overhangs, close to the vertical wall of the cliff. The wind cannot blow through the nests and break them. This is probably the reason the bees can extend the nest in a vertical direction. 2. The reason for asymmetrical nests is that there is a lack of space available to extend the comb equally in both external directions.

3. An asymmetrical nest also appears when remnants of a previous comb remain at one edge of the nest.

4. Convex nests are constructed to avoid excess sun exposure.

5. Concave combs are constructed as the result of low temperatures during the night and part of the day (Nepal).

6. The reason for constructing an L-shape nest is the lack of space available to extend the nest in a straight direction. Apis laboriosa bees do not construct L-shape combs. Instead, the bees extend the comb over and above the ceiling of the cliff overhang.

7. The nearby remnants of a previous comb force the bees to create a wavy nest.

8. A two-comb nest may materialize when a nest, which is growing, includes on its side an abandoned small stop-over, white comb.

9. The shape of the nest determines whether or not a comb falls.

10. An empty comb falls as a whole. It does not fall in parts. The upper part of the comb consists of pure wax cells where the honey was stored. When the night temperatures are low, those cells become brittle and are easily broken by the wind. As a result, the whole comb falls.

11. Abandoned combs of a vertical semi-ellipse shape are more susceptible to being broken by the wind than semi-circles or horizontal semiellipses.

12. Sometimes larger remnants of some combs remain at the attachment place. The reason for this is that the bee brood was reared in cells near the ceiling. The brood cells do not become brittle in lower temperatures and remained in place when the rest of the comb breaks off.

13. Concave or convex abandoned combs remain in place longer than straight ones. The reason is that curved combs cannot be twisted or bent by the wind.

14. Abandoned combs fall down as a whole. They do not fall down in parts, because the upper part of the combs, where the honey was stored, consists of pure wax cells which are brittle and breakable.

\section{ACKNOWLEDGEMENT}

We would especially like to thank Prof. dr Vasfi Gençer from Ankara University, Turkey, for his valuable suggestions, which improved the first version of this paper.

\section{Meteorological Conditions in Bangalore, India.}

Bangalore Monthly Climate Average, India http://www.worldweatheronline.com/ Bangalore-weather-averages/Karnataka/ IN.aspx

\section{REFERENCES}

Deodikar, G. B., Ghatge, A. L., Phadke, R. P., Mahindre, D. B., Kshirsagar, K. K., Muvel, S., \& Thakar, S. S. (1977). Nesting behaviour of Indian honeybees III. Nesting behavior of Apis dorsata Fab. Indian Bee Journal, $39(1-4), 1-12$.

http://jerzy_woyke.users.sggw.pl/1977_deodikar_ nesting_behavior.pdf

Kumar, G. M. N., \& Reddy, C. C. (2003). Nest density, dimension and distribution of Apis dorsata F. in relation to high and direction. Asian Bee Journal, 5(1\&2), 82-89.

Morse, R. A., \& Laigo, F. M. (1969). Apis dorsata in 


\section{WOYKE Ë Hl. - Reasons for the different nest shapes of Megapis}

the Phillipines (1969). Philippine_Association_of_Entomologist, INC pp. 96.

Reddy, C. C. (1 983). Studies on the nesting behaviour of Apis dorsata F., Proceedings of 2nd International Conference of Apiculture in Tropical Climate, New Delhi, pp. 391-397.

http://jerzy_woyke.users.sggw.pl/1983_reddy_ chandra.pdf

Reddy, M. S. (1988). Studies on the factors of selection of nesting site by Apis dorsata F. Thesis submitted to the Bangalore University for the degree of Doctor of Philosophy in the Faculty of Science. pp. 146.

http://jerzy_woyke.users.sggw.pl/1988_reddy_ ms.pdf

Woyke, J. (1997). Gospodarka krokwiowa z pszczoła olbrzymia [Rafter beekeeping with the giant honeybee]. Pszczelarstwo, 48(10), 4-5. (on line with English translation).

http://jerzy_woyke.users.sggw.pl/1997_gospod_ krokw_rafter.pdf

Woyke, J., Wilde, J., \& Wilde, M. (2001a). A scientific note on Apis laboriosa winter nesting and brood rearing in the warm zone of Himalayas. Apidologie, 32(6), 601 - 602. DOl: 10.1051/apido:2001 104

Woyke, J., Wilde, J., \& Wilde, M. (2001b). Swarming, migration and absconding of Apis dorsata colonies. Proceedings; VIII IBRA Conference on Tropical Bees, and V Asian Association Conference, Chiang Mai, 19 - 25 March, 2000: 183-188.

http://jerzy_woyke.users.sggw.pl/2001_ dorswarmchm.pdf

Woyke, J., Wilde, I., \& Wilde, M. (2003a). Periodic mass flights of Apis laboriosa in Nepal. Apidologie, 34 (2), 121-127. DOl: 10.1051/apido:2003002

Woyke, J., Wilde, J., \& Wilde, M. (2003b). Flight activity reaction to temperature changes in Apis dorsata, Apis laboriosa and Apis mellifera. Journal of Apicultural Science, 47(2), 73-80.

Woyke, J., Kruk, C., Wilde, J., \& Wilde, M. (2004). Peri- odic mass flights of the giant honey bee Apis dorsata. Journal of Apicultural Research, 43(4), 180-185. DOl:10.1080/00218839.2004.11101134

Woyke, J., Wilde, J., Wilde, M., Reddy, C., \& Cervancia, C. (2005a). Workers often predominate in dusk drone flights; of the giant honey bee Apis dorsata. Journal of Apicultural Research, 44(3), 130-132. DOl:10.10 80/00218839.2005.111101165

Woyke, J., Wilde, J., Reddy, C., \& Nagaraja, N. (2005b). Periodic mass flights of the giant honeybee Apis dorsata in successive days at two nesting sites in different environment conditions. Journal of Apicultural Research, 44(4), 80-89. D0l:10.1080/00218 839.2005.11101176

Woyke, J., Wilde, J., Wilde, M., Reddy, M. S., Nagaraja, N., \& Sivaram, V. (2007). Presence or absence of drones in drone; dusk mass flights performed by Apis dorsata foragers. Journal of Apicultural Research, 46(1), 40-49. DOl:10.1080/00218839.2007.11101365

Woyke, J., Wilde, J., Wilde, M., Sivaram, V., Cervancia, C., Nagaraja, N., \& Reddy, M. (2008). Comparison of defense body movements of Apis laboriosa, Apis dorsata dorsata and Apis dorsata breviligula honey bees. Journal of Insect Behavior, 27, 481-494. DOI 10.1007/s10905-008-9144-1

Woyke, J., Wilde, J., \& Wilde, M. (2012a). Swarming and migration of Apis dorsata and Apis laboriosa honey bees in India Nepal and Bhutan. Journal of Apicultural Science, 56 (1), 81-91. DOl: 10.2478/v10289012-0009-7

Woyke, J., Wilde, J., \& Wilde, M. (2012b). Which mountain cliffs do, A. laboriosa honeybees select as nesting sites and why? Journal of Apicultural Research, 57 (2), 193-303. DOl 10.3896/IBRA. 1.51.2.08 